\title{
Air pollution and stroke A new modifiable risk factor is in the air
}

\author{
M. Graber ${ }^{a}$, S. Mohr ${ }^{a}$, L. Baptiste ${ }^{a}$, G. Duloquin ${ }^{a}$, C. Blanc-Labarre ${ }^{a}$, \\ A.S. Mariet ${ }^{\mathrm{b}}$, M. Giroud ${ }^{\mathrm{a}}$, Y. Béjot ${ }^{\mathrm{a}}$
}

a : Dijon Stroke Registry (Inserm, Santé Publique France). EA7460 - University Hospital of Dijon University of Burgundy and Franche-Comté. Dijon-France

b: $\quad$ Clinical Investigation Center of Dijon (Inserm CIC 1432). University of Burgundy and Franche Comté, Inserm, Biostatistique, Biomathématique, Pharmacoepidemiologie et Maladies Infectieuses (B2 PHI), UMR 1181-University Hospital of Dijon

Epreuves et Tirés à part :

Pr Maurice Giroud

Service de Neurologie générale, vasculaire et dégénérative CHU Dijon Bourgogne - 14 Rue Paul Gaffarel - 21000 Dijon Tél. : 03.80.29.32.45 - Fax : 03.80.29.32.76

Mail : maurice.giroud@chu-dijon.fr 


\section{Abstract}

Evidence from epidemiological studies has demonstrated that outdoor air pollution is now a wellknown major problem of public health, mainly in low and middle income countries. Contrasting with myocardial infarction, there are few data on the association of air pollution and stroke.

Methods : We propose a narrative literature review of the effects and the underlying biological mechanisms of short- and long-term exposure to air pollutants on stroke risk and mortality, using the following key-words : stroke, cerebrovascular evens, ischemic and haemorrhage stroke, transient ischaemic attack, mortality, air pollution and air pollutants.

Results : Twenty one papers were selected. Air pollution, of which whose small particulate matter are the most toxic, contributes to about one-third of the global burden of stroke. We can identify vulnerable patients with classical neuro-vascular risk factors or a prior history of stroke or transient ischemic attack or persons living in low - income countries. Biological mechanisms of this new morbid association are discussed.

Conclusion : Air pollution should be recognized as a silent killer inducing stroke whose mortality rates remain elevated by its role as a new modifiable neuro-vascular risk factor, needing public health policies.

Key-words : Stroke, ischaemic and hemorrhagic stroke, , mortality, air pollution and air pollutants 


\section{Introduction}

Exposure to air pollution is now well recognized by scientists, media and the population as a major public health issue [1-6].

It ranks within the top five risk factors for mortality in emerging countries [1-6]. Forty per cent of all deaths could be induced by outdoor air pollution [4,5] and $89 \%$ of death attributed to ambient air pollution are observed in low and medium income countries as a result of rapid industrialization [7]. Robust data confirm the high risk of morbidity and mortality due to particulate matter measuring less than $2.5 \mu \mathrm{m}\left(\mathrm{PM}_{2.5}\right)$ for myocardial infarction and congestive heart failure $[4,6,8]$, lung disease and cancer $[1,4,9]$, diabetes [1] and Nitrogen dioxide $\left(\mathrm{NO}_{2}\right)$ for fetal growth in multiple pregnancy [10]. However, the association between air pollution and stroke overall and by subtype, is less clear $[6,11$ 14].

The recent works of the Global Burden of Disease study [15] which evaluated data from 1990 to 2013 in 188 developed and developing countries, demonstrated for the first time that air pollution contributed $30 \%$ to the burden of stroke. This new vascular risk factor can be considered as a potentially modifiable risk factor for stroke that is a major public health problem being the first cause of motor handicap and the second cause of cognitive disorder and death worldwide $[5,6,16]$.

The aim of this review is to clarify biological and clinical features of the association between air pollution and risk and mortality of stroke.

\section{Gaseous pollution is in the air}

Air pollution is a complex association of several components produced by different sources [6]. Air pollution includes small particulate matter (PM) and gaseous pollution consisting of ozone $\left(\mathrm{O}_{3}\right)$, sulfur dioxide $\left(\mathrm{SO}_{2}\right)$, nitrogen dioxide $\left(\mathrm{NO}_{2}\right)$ and carbon monoxide $(\mathrm{CO})$. $\mathrm{PM}_{2.5}$ represent $70 \%$ of $\mathrm{PM}$ measuring less than $10 \mu \mathrm{m}\left(\mathrm{PM}_{10}\right)$ [14] and they are able to penetrate into the alveoli of the lungs [14] and the brain cells [17].

Combustion of fossil energies, including motorized road traffic, power plants, industrial and home heating using coal, oil or wood [6], storms and volcanic eruptions, produces $\mathrm{PM}$ and $\mathrm{SO}_{2}$. Vehicle engine exhaust (mainly diesel engines) presents high levels of nanoparticles able to have a greater reactive area for a given mass [6].

$\mathrm{NO}_{2}$ and $\mathrm{CO}$ are produced by fuel combustion and $\mathrm{O}_{3}$ and is produced by photochemical reactions [18]. Air pollutant levels have spatial and temporal variations related to climate conditions (wind, temperature, sunlights, and rain) and geographic sources.

\section{Air pollution and stroke : epidemiological results}

\section{Methods}

Several resources were evaluated (PubMed, Web of Sciences, Embase) for publications in all languages available from 1960 through August 2018, using classical keywords : stroke, ischemic and hemorrhagic stroke, cerebrovascular disease, transient ischemic attack, incidence, mortality air pollution, air pollutants $\left(\mathrm{PM}_{2.5}, \mathrm{PM}_{10}, \mathrm{O}_{3}, \mathrm{NO}_{2}, \mathrm{CO}, \mathrm{SO}_{2}\right)$. We included all types of study design, evaluating short-term and long-term exposures to air pollutants, acute and chronic effects. 
To be eligible for the analysis of cause-effect association and its strength, studies should provide clear definitions of stroke [19] and air pollution [5]. Two investigators (MGr, MGi) evaluated all the eligible publications and the results were shared with all the authors.

\section{Results}

Cohort studies, ecological studies, case-crossover studies, daily time-series, observational studies, and big data evaluated effects of acute exposure to air pollutants. Cohorts and case-control studies evaluated chronic exposure $[5,11,14]$ (Table 1 ).

\section{Cohort studies}

Three studies are the most robust. Ljungman and Mittleman [20] demonstrated a strong association between long-term exposure to air pollutants and stroke mortality, from 6 cohorts studies. $\mathrm{NO}_{2}$ was associated to stroke mortality in 3 of the 6 studies. $\mathrm{NO}_{2}$ and PM were associated to hospitalization for stroke induced by long-term exposure to air pollutants.

Scheers et al [21], from 15 cohort studies observed that stroke risk was significantly associated to the rise of $\mathrm{PM}_{2.5}$ levels. The urban multiethnic cohort of Kulick et al [22] found evidence that within-city variation in residential proximity to major roadway was associated with higher risk of ischemic stroke among non current smoker.

\section{Ecological studies}

Nine studies [11,23-28] confirmed the positive association between air pollution and stroke and the decrease of out-door air pollution levels in developed countries contrasting with the increase of outdoor air pollution in developing countries [3 et 11].

The recent work of Zhang et al [24] demonstrated that the rise of $\mathrm{PM}_{2.5}$ was associated with the rise of both ischemic and hemorrhagic stroke mortality while the rise of $\mathrm{PM}_{10}$ was associated with only ischemic stroke mortality.

\section{Meta-analyses, time-series and case-crossover studies}

Henrotin et al $[29,30]$ provided new data showing that the association of ischemic stroke with air pollution significantly rose with the number of vascular risk factors (tobacco consumption, hypertension, hypercholesterolemia, and diabetes).

Yang et al [31] observed from a meta-analysis of 34 studies found another results with the association of the risk of ischemic strokes with several air pollutants $\left(\mathrm{PM}, \mathrm{SO}_{2}, \mathrm{CO}\right.$ and $\left.\mathrm{NO}_{2}\right)$. The meta-analysis of 94 studies by Shah et al [32] observed an increase of hospital admissions and mortality correlated with the rise of the pollutant levels. The meta-analysis including 45 studies by Wang et al [33] observed a significant association between the $\mathrm{PM}_{2.5}$ and $\mathrm{PM}_{10}$ levels and stroke mortality.

Guo et al [16] demonstrated in 2017 a borderline significant association between $\mathrm{NO}_{2}$, short-term exposure modeled as an averaged lag effect and ischemic stroke risk.

Maheswaran et al [34] demonstrated from the population-based case-crossover study in South London an association between an increased $\mathrm{NO}_{2}$ exposure with a higher risk of cerebrovascular small vessel disease, within the period 1995-2006. 
Contrasting with this positive association, Butland et al [35] did not find any association in 2017. It is a time-stratified case-cross over study, using data from the population-based study of South London from 2005 to 2012. They included 1311 incident ischemic strokes and 256 haemorrhagic strokes. The authors found no evidence for an association between all strokes or ischemic strokes and same day exposure to $\mathrm{PM}_{2.5}, \mathrm{PM}_{10}, \mathrm{O}_{3}, \mathrm{NO}_{2}$. For haemorrhagic strokes, they found a negative association with $\mathrm{PM}_{10}$ suggestive of a $14.6 \%$ fall in risk per $10 \mu \mathrm{g} / \mathrm{m}^{3}$ increase of pollutant. The change in air pollutants distribution may explain the discrepancy.

The time-series of Dong et al [36] demonstrated that short-term exposure to ambient $\mathrm{NO}_{2}$ was associated with increased ischemic stroke risk. In addition, $\mathrm{SO}_{2}$ was associated with increased ischemic stroke onset and death. The role of traffic-related air pollution has been well demonstrated with the cross-over study of Vivanco-Hidalgo et al [37].

Some geographical differences may explain these differences [21] or measurement errors [36]. Timestratified case-cross-over design may lead to reduced statistical power compared with a Poisson regression time-series approach [35].

\section{Big data}

Big data on stroke are now available in stroke disease and they deserve a special place. The Global Burden of Disease 2013 study [15,38] evaluated the population-attribuable risk of stroke-related disability-adjusted life-years associated with possible risk factors in 188 developed and developing countries from 1990 through 2013. They observed a significant higher proportion of stroke associated with air pollution, close to $30 \%$, higher in low-income and middle-income (33.7 \%) compared with high-income countries (10.2\%). They observed that only the low income and middle income countries, close to a fifth of stroke risk, was associated with solid fuel combustion in 2013 [15], confirming previous studies $[11,38]$. They used local available data in low and middle-income countries, and reported that ambient and house-hold air pollution was a new modifiable risk factor for stroke and a new public health problem, leading to new worldwide public health policies.

\section{The mechanisms of action of air pollution}

Beside the classical role of air pollution on inflammation, formation and rupture of atheroma plaque [39,40], endothelium dysfunction, cardiac arrhythmia, hypertension, activation of thrombosis [41] and vasoconstriction [5], new fundamental mechanisms may explain the association between air pollution and stroke [6].

\section{Translocation of nanoparticles}

The fact that nanoparticles fraction of PM pollution are able to cross the alveolar-capillary barrier towards the systemic circulation, they can directly impact on circulation blood cells [42], from a proinflammatory activation on endothelial cells [43]. Combusion-derived nanoparticles may regulate the adhesion of several molecules on the endothelial cells $[44,45]$. These multiple steps may explain the activation of monocytes and macrophages and increase endothelial cell permeability $[46,47]$.

The research on this new mechanism is difficult due to the small size and the number of small particles that will translocate, and to the technical difficulties to detect carbon-based nanoparticles in cells. The robust information is that nanoparticles can translocate quickly from lungs towards the blood circulation and areas of vascular inflammation [48]. 


\section{Autonomic dysfunction}

Inhaled small particles may disturb cardiovascular homeostasis via changes in autonomic function induced by activation of neural sensory receptors of the alveolar surface [6]. Some evidence is provided by reduction of heart rate variability after exposure du PM 2.5 [49], leading to atrial fibrillation [50-52] that is a major risk factor for stroke [5].

\section{Epigenetic mechanisms}

Epigenetic mechanisms such as post-translational modifications of DNA, RNA-related processes and histones may play an important role in the regulation of many vascular mechanisms [53], including endothelial stem/progenitor cell functions [54]. The clinical consequence is that blood DNA hypomethylation could be considered as a biomarker of atheroma [6] allowing to identify persons at risk of atheroma [55].

The role of DNA methylation on numerous genes contributing to stroke such as endothelial function $(54,56,57)$, the cytokine-mediated inflammatory reactions and coagulation [56,57], are another new way of research. Flavonoïs, methyl nutrients, folic acid, vitamin B12, may act on DNA methylation and may have a protective effect on prevention of stroke $[58,59]$.

We can identify several limitations of epidemiological studies, provided from most of developed countries where indoor exposure is not evaluated, individual exposures may be generalized to a larger area and it may be difficult to identify the cause of death that may be multiple. Earlier studies evaluated the combined effects of acute and chronic exposure to air pollutions.

\section{Screening people at risk}

Children and elderly people are more vulnerable to air pollution [13,34,60,61], such as Hispanics with diabetes [62], patients with previous vascular risk factors [29,30], people with recurrent stroke [5], patients with neighborhood deprivation living close to roadways or factories $[13,14,32]$, and people lining in low-income countries $[15,38]$.

Finally, greater exposure to air pollution on previous cardiovascular risk factors is associated with a greater risk of stroke [34].

\section{Possible recommendations}

Therefore, epidemiology and experimental evidence demonstrate that there is no safe air pollution and that it is necessary to promote public health policy to eradicate both indoor and outdoor air pollution worldwide [6,15], reducing individual and collective combustion of fossil fuels and developing future urban planning including robust monitoring and protection from air pollution [5]. For medical practice, it is necessary to recall that epidemiological studies have shown that people at risk during an acute air pollution exposures are elderly people, as well as people with previous vascular risk as blood hypertension, diabetes, hypercholesterolemia, atrial fibrillation, sleep apnea or tobacco consumption [5].

\section{Conclusion}


A new modifiable risk factor for stroke is in the air. Epidemiological studies have demonstrated the significant association between air pollution and stroke. New fundamental mechanisms described suggest urgent effective strategy.

\section{Disclosure of interest}

No Financial or personnal conflicts or relationship. 


\section{References}

[1] Desikan A. Outdoor air pollution as a possible modifiable risk factor to reduce mortality in post-stroke population. Neurol Regeneration Research 2017;3:351-3.

[2] Delpont B, Mariet AS, Blanc C, Béjot $Y$, Giroud M. Environmental air pollution : an emerging risk factor for stroke. Encyclop Cardio Vasc Res Med 2018;2:231-7.

[3] World Health Organization. Air quality deteriorating in many of the world's cities, www.who.int/mediacentre/news/releases/2014/air-quality (2014, accessed 7 April 2018).

[4] Anderson JO, Thundiyil JG and Stolbach A. Clearing the air: a review of the effects of particular matter air pollution on human health. J Med Toxicol 2012;8:166-75.

[5] Béjot $Y$, Reis J, Giroud M, Feigin V. A review of epidemiological research on stroke and dementia and exposure to air pollution. International Journal of stroke 2018;doi:10$1117 / 1747493018772800$.

[6] Lee KK, Miller MR, Shah AD. Air pollution and stroke. Journal of Stroke 2018;20(1):2-11.

[7] Landrigan PJ, Fuller R, Acosta NJR, Adeyi O, Arnold R, Basu NN et al. The Lancet Commission on pollution and health. Lancet 2017 Oct 19 [Epub]. https://doi.org/10.1016/S01406736(17)32345-0.

[8] Mustafic $\mathrm{H}$, Jabre $\mathrm{P}$, Caussin $\mathrm{C}$, Murad MH, Escolano S, Tafflet $\mathrm{M}$ et al. Main air pollutants and myocardial infarction : a systematic review and meta-analysis. JAMA 2012;307:713-21.

[9] Raaschou-Nielson O, Andersen Z, Beelen R, Samoli E, Stafoggia M, Weinmayr G et al. Air pollution and lung cancer incidence in 17 European cohorts : prospective analysis from the European Study of Cohorts for Air Pollution Effects (ESCAPE). Lancet Oncol 2013;14:813-22.

[10] Mariet AS, Mauny F, Pujol S, Thiriez G, Sagot P, Riethmuller D et al. Multiple pregnancies and air pollution in moderately polluted cities : is there an association between air pollution and fetal growth. Environment International 2018;121:890-7.

[11] Maheswaran R, Pearson T, Smeeton NC, Beevers SD, Campbell MJ, Wolfe CD et al. Impact of outdoor air pollution on survival after stroke : population-based cohort study. Stroke 2010;41:869-77.

[12] Wilker EH, Mostofsky E, Lue SH, Gold D, Schwartz J, Wellenius GA et al. Residential proximity to high-traffic roadways and poststroke mortality. J Stroke Cerebrovasc Dis 2013;22:e366e372.

[13] Desikan A, Crichton S, Hoang U, Barrat B, Beevers SD, Kelly FJ et al. Effect of exhaust- and non-exhaust-related components of particulate matter on long-term survival after stroke. Stroke 2016;47:2916-22.

[14] Maheswaran R. Air pollution and stroke. An overview of the evidence base. Spatiotemporal Epidemiol 2016;18:74-81. 
[15] Feigin VL, Roth GA, Nathavi M, Parmar P, Krishanamurthi R, Chugh S et al. Global Burden of stroke and risk factors in 188 countries, during 1990-2013 : a systematic analysis for the Global Burden of Disease Study 2013. Lancet Neurol 2016;15:913-24.

[16] Guo P, Wang Y, Feng W, Wu J, Fu C, Deng H et al. Ambient air pollution and risk for ischemic stroke : a short-term exposure assessment in South China. Int J Environ Res Public Health 2017;14:1091-102.

[17] Maher BA, Ahmed IA, Karloulovsky V, Mac Laren DA, Foulds PG, Allsop D et al. Magnetite pollution nanoparticles in the human brain. PNAS 2016;113:1797-801.

[18] Cassee FR, Heroux ME, Gerlofs-Nijland ME, Kelly FJ et al. Particulate matter beyond mass : recent health evidence on the role of fractions, chemical constituent and sources of emission. Inhal Toxicol 2013;25:802-12.

[19] Adams JH, Bendixen B, Kapelle L, Biller J, Love B, Gordon D et al. Classification of subtype of acute ischemic stroke. Definitions for use in a multicenter clinical trial. TOAST trial of Org 10172 in acute stroke treatment. Stroke 1993;24:35-41.

[20] Ljungman PL and Mittleman MA. Ambient air pollution and stroke. Stroke 2014;45:373441.

[21] Scheers H, Jacobs L, Casas I, Nemery B, Nawrot TS et al. Long-term exposure to particulate matter air pollution is a risk factor for stroke : meta-analytical evidence. Stroke 2015;46:3058-66

[22] Kulick ER, Wellenius GA, Boehme AK, Sacco RL, Elkind MS. Residential proximity to major roadways and risk of incident ischemic stroke in NOMAS (The Northern Manhattan Study). Stroke 2018;49:835-41.

[23] Hu Z, Liebens J and Rao KR. Linking stroke mortality with air pollution, income and greenness in northwest Florida : an ecological geographical study. Int J Health Geogr 2008;41:131925 .

[24] Zhang R, Liu G, Jiang Y, Li G, Pan Y, Wang Y et al. Acute effects of particulate air pollution on ischemic stroke and hemorrhagic stroke mortality. Frontiers in Neurology 2018;doi:10.3389/fneur.2018.00827.

[25] Maheswaran R and Elliot R. Stroke mortality associated with living near main roads in England and Wales-a geographical study. Stroke 2003;34:2776-80.

[26] Tsai S, Goggins WB, Chiu H, Yang C. Evidence for an association between air pollution and daily stroke admissions in Kaohsiung, Taiwan. Stroke 2003;34:2612-6.

[27] Wellenius GA, Schwartz J, Mittleman MA. Air pollution and hospital admissions for ischemic and hemorrhagic stroke among Medicare beneficiaries. Stroke 2005;36:2549-53.

[28] Iribarren C, Darbinian J, Klatsky AL, Friedman GD. Cohort study of exposure to environmental tobacco smoke and risk of first ischemic stroke and transient ischemic attack. Neuroepidemiology 2004;23:38-44. 
[29] Henrotin JB, Besancenot JP, Bejot Y, Giroud M et al. Short-term effects of ozone air pollution on ischemic stroke occurrence : a case-crossover analysis from a 10-year population-based study in Dijon, France. Occup Environ Med 2007;64:439-45.

[30] Henrotin JB, Zeller M, Lorgis L, Cottin Y, Giroud M, Béjot $Y$ et al. Evidence of the role of shortterm exposure to ozone on ischemic cerebral and cardiac events : the Dijon Vascular Project (DIVA). Heart 2010;96:1990-6.

[31] Yang WS, Wang $X$, Deng $Q$, Wy $F$, Wy $W$ et al. An evidence-based appraisal of global association between air pollution and risk of stroke. Int J Cardiol 2014;175:307-13.

[32] Shah AS, Lee KK, McAllister DA, Hunter A, Nair H, Whiteley W et al. Short term exposure to air pollution and stroke : systematic review and meta-analysis. BMJ 2015;350:h1295.

[33] Wang $\mathrm{Y}$, Eliot $\mathrm{N}$, Wellenius $\mathrm{GA}$. Short-term changes in ambient particulate matter and risk of stroke : a systematic review and meta-analyses. J Am Heart Assoc 2014;3:e00093.

[34] Maheswaran K, Pearson T, Beevers SD, Campbell MJ and Wolfe CD. Air pollution and subtypes, severity and vulnerability to ischemic stroke. A population-based case-crossover study. PLoS One 2016;11:e0158556.

[35] Butland BK, Atkinson RW, Crichton S, Baratt B, Beevers S, Spiridon A et al. Air pollution and the incidence of ischaemic and haemorrhagic stroke in South London Stroke Register : a casecross-over analysis. J. Epidemiol. Community Health 2017;71:707-12.

[36] Dong H, Yu Y, Yao S, Lu Y, Chen Z, Li G et al. Acute effects of air pollution on ischaemic stroke onset and deaths: a time-series study in Changzhou, China. BMJ Open 2018;doi:10.1136/bmjopen-2017-202425.

[37] Vivanco-Hidalgo RM, Wellenius G, Basoganor-Cirah M, Gomez-Gonzalez A, De Ceballos P et al. Short-term exposure to traffic-related air pollution and ischemic stroke onset in Barcelone, Spain. Environmental Research 2018;162:160-5.

[38] Brauer M, Freedman G, Frostad J et al. Ambient air pollution exposure estimation for the Global Burden of Disease 2013.Environ Sci Technol 2016;50:79-88.

[39] Bai N, Kido T, Suzuki H, Yang G, Kavanagh TJ, Kaufman JD et al. Changes in atherosclerotic plaques induced by inhalation of diesel exhaust. Atherosclerosis 2011; 216: 299-306.

[40] Bauer M, Moebus S, Möhlenkamp S, Dragano N, Nonnemacher M, Fuchsluger M et al.; HNR Study. Investigative Group. Urban particulate matter air pollution is associated with subclinical atherosclerosis results from the HNR (Heinz Nixdorf Recall) study. JACC 2010; 56: 1803-08.

[41] Newby DE, Mannucii PM, Tell GS, Baccarelli AA, Brook RD, Donaldson K et al. ESC working group on thrombosis. European association for Cardio vascular prevention and rehabilitation. ESC heart failure association. Expert position paper on air pollution and cardiovascular disease. Eur Heart J 2015; 36: 83-93.

[42] Oberdörster G, Sharp Z, Atudorei V, Elder A, Gelein R, Lunts A, et al. Extrapulmonary translocation of ultrafine carbon particles following whole-body inhalation exposure of rats. J Toxicol Environ Health A 2002;65:1531-43. 
[43] Aung HH, Lame MW, Gohil K, He G, Denison MS, Rutledge JC, et al. Comparative gene responses to collected ambient particles in vitro: endothelial responses. Physiol Genomics 2011;43:917-29.

[44] Lee CC, Huang SH, Yang YT, Cheng YW, Li CH, Kang JJ. Motorcycle exhaust particles upregulate expression of vascular adhesion molecule-1 and intercellular adhesion molecule-1 in human umbilical vein endothelial cells. Toxicol In Vitro 2012;26:552-60.

[45] Montiel-Dávalos A, Alfaro-Moreno E, López-Marure R. PM2.5 and PM10 induce the expression of adhesion molecules and the adhesion of monocytic cells to human umbilical vein endothelial cells. Inhal Toxicol 2007;19 Suppl 1:91-8.

[46] Chao MW, Kozlosky J, Po IP, Strickland PO, Svoboda KK, Cooper K, et al. Diesel exhaust particle exposure causes redistribution of endothelial tube VE-cadherin. Toxicology 2011;279:73-84.

[47] Li R, Ning Z, Cui J, Yu F, Sioutas C, Hsiai T. Diesel exhaust particles modulate vascular endothelial cell permeability: implication of ZO-1 expression. Toxicol Lett 2010;197:163-8.

[48] Miller MR, Raftis JB, Langrish JP, McLean SG, Samutrtai P, Connell SP, et al. Inhaled nanoparticles accumulate at sites of vascular disease. ACS Nano 2017;11:4542-52.

[49] Pieters N, Plusquin M, Cox B, Kicinski M, Vangronsveld J, Nawrot TS. An epidemiological appraisal of the association between heart rate variability and particulate air pollution: a meta-analysis. Heart 2012;98:1127-35.

[50] Wang T, Lang GD, Moreno-Vinasco L, Huang Y, Goonewardena SN, Peng YJ, et al. Particulate matter induces cardiac arrhythmias via dysregulation of carotid body sensitivity and cardiac sodium channels. Am J Respir Cell Mol Biol 2012;46:524-31.

[51] Nadziejko C, Fang K, Narciso S, Zhong M, Su WC, Gordon T, et al. Effect of particulate and gaseous pollutants on spontaneous arrhythmias in aged rats. Inhal Toxicol 2004;16:373-80.

[52] Chung JW, Bang OY, Ahn K, Park SS, Park TH, Kim JG, et al. Air pollution is associated with ischemic stroke via cardiogenic embolism. Stroke 2017;48:17-23.

[53] Hu Z, Zhong B, Tan J, Chen C, Lei Q, Zeng L et al. The emerging role of epigenetics in cerebral ischemia. Mol Neurobiol 2017; 54:1887-1905.

[54] Fraineau S, Palii CG, Allan DS, Brand $M$ et al. Epigenetic regulation of endothelial-cellmediated vascular repair. FEBS J2015; 282: 1605-29.

[55] Baccarelli A, Wright R, Bollati V, Litonjua A, Zanobetti A, Tarantini L et al. Ischemic heart disease and stroke in relation to blood DNA methylation. Epidemiology 2010; 21: 819-28.

[56] Bind MA, Peters A, Koutrakis P, Coull B, Vokonas P, Schwartz J. Quantile regression analysis of the distributional effects of air pollution on blood pressure, heart rate variability, blood lipids, and biomarkers of inflammation in elderly American men: the normative aging study. Environ Health Perspectives 2016;124: 1189-98. 
[57] Dai L, Bind MA, Koutrakis P, Coull BA, Sparrow D, Vokonas PS et al. Fine particles, genetic pathways, and markers of inflammation and endothelial dysfunction: analysis on particulate species and sources. J Expo Sci Environ Epidemiol 2016; 26: 415-21.

[58] Zhong J, Colicino E, Lin X, Mehta A, Kloog I, Zanobetti A et al. Cardiac autonomic dysfunction: particulate air pollution effects are modulated by epigenetic immunoregulation of toll- like receptor 2 and dietary flavonoid intake. J Am Heart Assoc 2015; 4:e001423, doi:10.1161/JAHA.114.001423.

[59] Byrne MM, Murphy RT and Ryan AW. Epigenetic modulation in the treatment of atherosclerotic disease. Front Genet 2014; 5: 1-7.

[60] Sacks JD, Stanek LW, Luben TJ, Johns DO, Buckley BJ, Brown JS et al. Particulate matterinduced health effects: who is susceptible? Environ Health Perspect 2011; 119: 446-54.

[61] Sade MY, Novack V, Ifergane G, Horev A, Kloog I. Air pollution and ischemic stroke among young adults. Stroke 2015; 46:3348-53.

[62] O'Donnell MJ, Fang J, Mittleman MA, Kappral MA, Wellenius GA. Fine particulate air pollution (PM2.5) and the risk of acute ischemic stroke. Epidemiology 2011; 22: 422-31. 
Table 1. Clinical studies on stroke and air pollutions

\begin{tabular}{|c|c|c|c|c|}
\hline & Cohort Studies & Ecological studies & $\begin{array}{c}\text { Meta-analyses, time-series and case-crossover } \\
\text { studies }\end{array}$ & Big-data \\
\hline $\begin{array}{l}\text { Clinical } \\
\text { studies on } \\
\text { stroke and } \\
\quad \text { air } \\
\text { pollutions }\end{array}$ & $\begin{array}{l}\text { - Ljungman and Mittleman [20] }=6 \\
\text { cohort studies (UK, USA, Denmark, } \\
\text { Japan) } \\
\text { - Scheers et al [21] = } 20 \text { cohort studies } \\
\text { (USA, Europe, Asia) } \\
\text { - Kulick et al [22] = } 1 \text { population-based } \\
\text { cohort in Northern Manhattan (USA) }\end{array}$ & $\begin{array}{l}\text { - Maheswaran et al [11]. South London } \\
\text { (UK) } \\
\text { - } \quad \text { Hu et al [23]. Florida (USA) } \\
\text { - } \text { Zang et al [24] in Beijing (China) } \\
\text { - Maheswaran and Elliot [25]. England } \\
\text { - } \text { and Wates (UK) } \\
\text { - } \quad \text { Wellenius et al [27] in } 9 \text { US cities } \\
\text { - } \quad \text { Iribarren et al [28] in San Francisco } \\
\text { (USA) }\end{array}$ & $\begin{array}{l}\text { - } \text { Guo et al [16] in Guangzhou (China) } \\
\text { - } \text { Henrotin et al [29,30] = } 1 \text { cross-over study in } \\
\text { Dijon (France) } \\
\text { - } \text { Sang et al [31] = } 1 \text { meta-analysis from } 34 \\
\text { - Shah et al [32] = } 1 \text { meta-analysis from } 94 \\
\text { studies } \\
\text { - Wang et al [33] = } 1 \text { meta-analysis of } 45 \\
\text { studies } \\
\text { - Maheswaran R et al [34] in South London } \\
\text { (UK) } \\
\text { - Butland et al [35] = 1 cross-over study from a } \\
\text { community-based study in London (UK) } \\
\text { - Dong et al [36] = } 1 \text { time-series in Changzhou } \\
\text { (China) } \\
\text { Vivanco-Hidalgo et al [37] = } 1 \text { cross-over } \\
\text { study from a hospital-based study in } \\
\text { Barcelone (Spain) }\end{array}$ & $\begin{array}{l}\text { - } \text { Feigin et al [15] } \\
\text { in worldwide } \\
\text { - Brauer et al } \\
\text { [38] in } \\
\text { worldwide }\end{array}$ \\
\hline
\end{tabular}

